\title{
Contractual Governance, Relational Governance: Why Do Firms Continue Drafting Contracts?
}

\author{
Jacques Boulay, PhD, ESSCA School of Management, LUNAM Université, France
}

\begin{abstract}
Governing relationships effectively is central to marketing channel performance. Relational governance theory singles out two key mechanisms, contracts and norms, and suggests that norms surpass contracts in their ability to minimize opportunistic behaviour. Recent research has disputed that perspective though, by noting the dark side of norms and calling for a renewed perspective on contractual governance. An analysis of existing empirical research on contractual versus relational governance of marketing channels leads into the proposal of four research directions that can help better understand why firms keep drafting contracts.
\end{abstract}

Keywords: Contractual Governance; Relational Governance; Marketing Channel Performance, Opportunism

\section{INTRODUCTION}

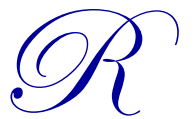

esearch on the governance of marketing channels emphasizes the use of relational norms to curb opportunism within channel relationships, while stressing that the effectiveness of detailed contracts is a topic of some controversy (Achrol and Gundlach, 1999; Berthon et al., 2003; Cannon et al., 2000; Ferguson et al., 2005; Jap and Ganesan, 2000; Lusch and Brown, 1996; Wuyts and Geyskens, 2005; Young and Wilkinson, 1989). One may then wonder why channel members continue to use contracts to govern the relationships with their business partners. Indeed, detailed contracts remain a central coordination mechanism in marketing channels, buyer-seller agreements, franchise contracts, and licensing contracts getting signed every day.

The adoption of the relational paradigm by the marketing literature may have led researchers to a too rapid emphasis on the use of norms to govern channel relationships. Besides, existing studies on contractual governance present some limitations as to the way of measuring the phenomenon. Last but not least, the measure of the governing effects of contracts are somewhat unclear, one reason being that parties rarely refer to the contract once it has been signed.

Based on an analysis of the contributions and limitations of the marketing literature on the governance of channel relationships, this article proposes a series of research directions to renew the investigative framework about the use of contracts as a governance mechanism.

\section{GOVERNANCE OF EXCHANGE RELATIONSHIPS}

The theory of relational governance draws on the analysis of McNeil $(1974,1980)$, who himself drew on MacCaulay's (1963) research on noncontractual business relationships. According to MacCaulay (1963), contracts and contract law tend to be useless and could even have undesirable consequences for interfirm relationships, especially considering the many extra-legal sanctions available to manage relationships. For example, an organization's reputation might be tarnished by unfulfilled commitments.

When a contract is inscribed within a business relationship, the contractual obligations often get modified, added to, or even replaced by relational norms. Therefore, McNeil offers a more flexible contract law to deal with 
the increasing difficulty of planning for all contingencies in a business relationship, especially in uncertain environments (Hadfield, 1990; McNeil 1974, 1980; Spriggs, 1996). Because an exchange is possible as soon as both partners reach an agreement, whether its details are fixed or not, the exchange context can be represented on a continuum with one-shot or discrete transactions - characterized by limited communication and narrow content-at one end and relational transactions - defined as long-term, complex, continuous relationships-at the other end (Lusch and Brown, 1996).

The shift from a transactional to a relational paradigm has prompted a vast body of research in marketing. Its richness is reflected in the diversity of the terminology used to illustrate the two modes of governance (see Table 1).

Table 1: Discrete versus relational governance

\begin{tabular}{|c|c|c|}
\hline \multirow[b]{2}{*}{ Authors } & \multicolumn{2}{|c|}{ Exchange Continuum } \\
\hline & Discrete exchange & $\begin{array}{r}\text { Relational exchange } \\
\end{array}$ \\
\hline McNeil $(1974,1980)$ & Discrete norms & Relational norms \\
\hline Jeuland and Shugan (1983) & Simple contract & Implicit understandings \\
\hline Gundlach and Achrol (1993) & Authority-based governance & Social norms governance \\
\hline Heide (1994) & Unilateral/hierarchical governance & Bilateral governance \\
\hline Weitz and Jap (1995) & Contractual control & Normative control \\
\hline Lusch and Brown (1996) & Explicit contract & Normative contract \\
\hline Cannon et al. (2000) & Contractual agreement & Relational social norms \\
\hline Jap and Ganesan (2000) & Explicit contract & Relational norms \\
\hline Anderson and Coughlan (2002) & Formal contract & Informal contract \\
\hline Ferguson et al. (2005) & Contractual governance & Relational governance \\
\hline Wuyts and Geyskens (2005) & Detailed contract drafting & Close partner selection \\
\hline Boulay (2010) & Contract & Norms \\
\hline
\end{tabular}

Marketing research aims at evaluating the effectiveness of formal or explicit contracts compared with that of informal or implicit contract (norms), in terms of their impacts on exchange partners' behaviors, attitudes, or performance within a relationship.

\section{CONTRACTUAL GOVERNANCE OF EXCHANGE RELATIONSHIPS: A COUNTERPRODUCTIVE MECHANISM?}

Contracts are "detailed, binding legal agreements that specify the obligations and role of both parties. As such, contracts can be considered substitutes for the formal governance mechanisms of hierarchy or integration in business to business exchanges" (Ferguson et al., 2005). Table 2 summarizes the findings of key research into the efficiency of contracts for governing exchange relationships in marketing channels.

Table 2: Contractual governance, behavior/attitude, and performance

\begin{tabular}{|l|l|c|c|}
\hline \multicolumn{1}{|c|}{ Authors } & Governance Mechanism & Impact on Behavior/Attitude & Impact on Performance \\
\hline Boulay (2010) & Contract & + (compliance) & \\
\hline Wuyts and Geyskens (2005) & Detailed contract drafting & ns (opportunism) & \\
\hline Ferguson et al. (2005) & Contractual governance & & + (exchange performance) \\
\hline Cannon et al. (2000) & Contractual agreement & & + (performance) \\
\hline Jap and Ganesan (2000) & Explicit contract & - (commitment) & \\
\hline Achrol and Gundlach (1999) & Legal contract & ns (relational behavior) & ns (economic performance) \\
\hline Lusch and Brown (1996) & Explicit contract & + (conflict) & \\
\hline Young and Wilkinson (1989) & Written contract & \\
\hline
\end{tabular}

ns: non-significant result

Counter intuitively, findings suggest that contracts are not an effective way to govern relationships within marketing channels. A relationship based on a detailed/formalized contract might lead either to more conflict (Young and Wilkinson, 1989) or to less commitment from the exchange partners (Jap and Ganesan, 2000). Most studies show no effect at all (Achrol and Gundlach, 1999; Lusch and Brown, 1996; Wuyts and Geyskens, 2005), with the exception of Boulay (2010) in the franchise context. 
Other research has sought to measure the effectiveness of contractual governance on exchange partners' performance. Cannon et al. (2000) detected a positive effect when the exchange context is characterized by a low level of transactional uncertainty. Ferguson et al. (2005) further showed that contractual governance related positively to exchange performance in the context of interfirm service exchanges.

These empirical findings - especially in relation to hedging opportunism - challenge the theory of contract law which stipulates that contracts are used to reduce opportunistic behavior and the resulting uncertainty by establishing formal rules and procedures, which reinforce parties' commitment to the relationship.

One explanation is that individuals have a level of authority acceptance, within which the benefits of accepting authority are greater than its disadvantages, so negative reactions arise when this level is exceeded (Buckling, 1973). Writing detailed contracts creates rigidities (Wuyts and Geyskens, 2005) that may prompt reactions such as a reduced emotional investment in the relationship, a search for other sources of gratification, investment in reaching their own goals, or the denial of sources of power to the exchange partner that would enable him to reach his own goals (Emerson, 1962).

\section{RELATIONAL GOVERNANCE OF EXCHANGE RELATIONSHIPS: FROM PROVEN EFFECTIVENESS TO THE DARK SIDE}

Relational governance is defined "as an endogenous mechanism that can enhance exchange performance by embedding private and public information flows in a matrix of social ties rather than by resorting to contract or its enforcement by a third party, such as courts" (Ferguson et al., 2005). Norms bind exchange partners together by prescribing acceptable behaviors (Heide and John, 1992). As Table 3 summarizes, empirical research offers several insights into the role of norms as a mechanism for governing exchange relationships.

Table 3: Relational governance, behavior/attitude, and performance

\begin{tabular}{|c|c|c|c|}
\hline Authors & Governance Mechanism & Impact on Behavior/Attitude & Impact on Performance \\
\hline Boulay (2010) & Norms & - (compliance) & \\
\hline Wuyts and Geyskens (2005) & Close partner selection & U-shaped effect on opportunism & \\
\hline Ferguson et al. (2005) & Contractual governance & & $+($ exchange performance $)$ \\
\hline Brown et al. (2000) & Relational exchange & - (opportunism) & \\
\hline Jap and Ganesan (2000) & Relational norms & $+($ commitment $)$ & \\
\hline Cannon et al. (2000) & Cooperative norms & & + (performance) \\
\hline Achrol and Gundlach (1999) & Relational norms & - (opportunism) & \\
\hline Joshi and Arnold (1997) & Relational norms & - (opportunism) & \\
\hline Brown and Dev (1997) & Relationship performance & & + (performance) \\
\hline Lusch and Brown (1996) & Normative contract & + (relational behavior) & $+($ economic performance $)$ \\
\hline Gundlach et al. (1995) & Relational social norms & $\begin{array}{l}\text { - (opportunism) } \\
+ \text { (commitment) }\end{array}$ & \\
\hline Noordewier et al. (1990) & Relational governance & & + (quantitative performance) \\
\hline Young and Wilkinson (1989) & Unwritten contract & - (conflict) & \\
\hline
\end{tabular}

When exchange relationships are governed by higher levels of relationalism, exchange partners exhibit fewer opportunistic behaviors (Brown et al., 2000; Gundlach et al., 1995; Jap and Anderson, 2001) and stronger commitment to the relation (Gundlach et al., 1995; Jap and Ganesan, 2000; Lusch and Brown, 1996). Relational norms also serve as a moderator between channel members' dependence and opportunism (Achrol and Gundlach, 1999; Joshi and Arnold, 1997). These results explain why most research considers relational governance as an effective mechanism for curbing opportunistic behavior.

But Wuyts and Geyskens (2005) found recently that close partner selection effects on opportunism were Ushaped: initially effective in hedging again opportunistic behavior, then increasing rather than attenuating opportunism. They call this effect "the dark side" of relationalism. Boulay (2010) confirmed that result by establishing that high levels of relational norms in franchise relationships were linked to less franchisees' compliance with their franchisor's directives. These results are in line with Hibbard et al.'s (2001) finding that the positive effects of relational marketing - trust, commitment, communication, shared values, and dependencedeclined over time. 
Overall, relational governance literature thus indicates, nearly from the start (Noordewier et al., 1990; Young and Wilkinson, 1989), that contracts are less efficient than relational norms to monitor opportunistic behavior and performance within marketing channels. Yet more recent studies show that in certain circumstances, this assumption simply is not true. Moreover, channel members keep drafting detailed agreements. We believe that one central explanation for these results is that their authors missed some conceptual and methodological points.

\section{UNDERSTANDING WHY FIRMS KEEP DRAFTING CONTRACTS: RESEARCH DIRECTIONS}

The first two research directions we offer have to do with understanding and evaluating the contractual governance of exchange relationships. We then follow with two directions about the need to study plural systems of governance and to use a contingency perspective in future research frameworks.

\section{Capacity for contractual governance}

Faced with research findings that suggest that contractual governance has either no or a negative effect on opportunistic behaviors, some authors are tempted to revise contract theory by stressing that exchange contracts are not designed to limit opportunistic behaviors (Achrol and Gundlach, 1999). Beyond questioning the role of contracts in the design of channel relationships, this reasoning questions the way researchers measure the contractual governance of channel relationships.

The contractual governance concept is quite similar to the notion of formalization (i.e., a set of explicit rules and procedures on which channel members base their decisions [Anderson and Coughlan, 2002]), and yet the empirical findings from these two research streams do not match. Research into the formalization of channel relationships indicates that formalized exchange relations relate to less opportunistic behaviors and channel members' positive attitudes (e.g., Boyle 1994; Dahlstrom and Nygaard, 1995, 1999).

Marketing scholars investigating contractual governance of marketing relationships should use a measure of the phenomenon based on its capacity, rather than on its intensity. By asking channel members if their contract clearly delineates each channel members' role, details precisely what will happen in case of conflict, and so forth, researchers have missed a central point: Do exchange partners see contracts as a governance mechanism? Research based on a capacity approach could then lead to a less deterministic measure compared to today's models, by questioning channel members not about the contractual specifications of the exchange relationship but rather about their perception of the contractual monitoring of the relationship.

\section{Acceptance of contractual governance}

Organizational research suggests that a fairly wielded authority increases the chances that the members of an organization will accept it and will then exhibit higher levels of motivation and of satisfaction toward the organization (Tyler, 1988).

This concept of fairness has attracted growing interest among marketing researchers; many authors have called for its use to specify behaviors within marketing channels (Kumar et al., 1995; Sindhav, 2001). Dwyer et al. (1987) stress its importance as a central element for building strong relational exchanges. Samaha et al. (2011) also note that perceived unfairness by a channel member can act as a "relationship poison by directly damaging relationships, aggravating the negative effects of both conflict and opportunism, and undermining the benefits of using contracts to manage channel relationships."

In turn, research on contractual governance should better integrate this fairness perspective into its conceptual frameworks. One research direction is to determine the moderating role of contract fairness on the link between contractual governance and opportunism. Researchers should also examine if using contract acceptance as a moderator, rather than contract capacities, can provide more fine-grained results. 


\section{Plural systems of governance}

Based on Bradach and Eccles's (1989) "price-authority-trust" system, marketing scholars have attempted to find appropriate plural systems of governance to hedge opportunistic behaviors and reinforce channel performance. A widespread assumption holds that governance mechanisms complement, rather than oppose or substitute for, one another. Thus, if the contract can provide a general framework for the relationship, daily performance is usually governed by relational norms (Achrol and Gundlach, 1999).

Research in support of these predictions is limited and somewhat contradictory though. Gundlach and Achrol (1993) find that relational governance relates inversely to contractual governance (i.e., the effects of contracts and norms cancel each other). Cannon et al. (2000) suggest that the role of contracts becomes more important when social safeguards exist while Wuyts and Geyskens (2005) observe that detailed contract drafting and close partner selection are complementary in fighting opportunism. Boulay (2010) demonstrates that the effects of contractual governance on franchisees' compliance decrease with the level of relational governance.

These results indicate that further research is needed to understand the effectiveness of plural governance strategies based on a "contract + norms" combination. Research could integrate, within this combination, additional governance mechanisms, such as partner selection procedures, the use of information systems to monitor channel activities, and so forth. Defining an open governance system could then extend our understanding of channel members' reactions to each governance mechanism, whether used solely or simultaneously.

\section{Contingent perspective}

While discussing the inadequacy of using legal contracts in uncertain environments, Cannon et al. (2000) promote a contingency approach when considering channel members' reactions to contracts. They suggest that what matters most is not the contract by itself but the social context within which it is used. In environments with no uncertainty, the need to specify future performance through contracts diminishes (Achrol and Gundlach, 1993).

In addition to adopting this perspective, future research frameworks should include the impact of time on the effectiveness of each governance mechanism. Conventional wisdom implies that the effectiveness of a governance mechanism evolves over time with the evolution of the life cycle of the exchange relationship. One hypothesis is that contract will be useful to govern channel members' behaviors by enforcing standards and rules at the beginning of the relationship or at the end (in case of conflict) while relational norms will serve as a deterrent to opportunism during the growth stage of the relationship.

Finally, dependence and power relations between channel members are two other variables that future models should include, because they can help explain variations in evaluations of the impact of governance mechanisms on channel members' cooperation (Samaha et al., 2011).

\section{AUTHOR INFORMATION}

Jacques Boulay, Ph.D., ESSCA School of Management, LUNAM Université, 1, rue Lakanal, 49000, Angers, France. E-mail: jacques.boulay@essca.fr

\section{REFERENCES}

1. Achrol, R.S. and Gundlach, G.T. (1999). Legal and social safeguards against opportunism in exchange. Journal of Retailing, 75 (1) 107-124.

2. Anderson, E. and Coughlan, A.T. (2002). Channel management: structure, governance and relationship management, in Handbook of Marketing, eds. B. Weitz and R. Wensley. Thousand Oaks, CA: Sage, 223247.

3. Berthon, P., Pitt, L.F., Ewing, M.T., and Bakkeland, G. (2003). Norms and power in marketing relationships: alternative theories and empirical evidence. Journal of Business Research, 56 (9) 699-709. 
4. Boulay, J. (2010). The role of contract, information systems and norms in the governance of franchise systems. International Journal of Retail \& Distribution Management, 38 (9) 662-676.

5. Boyle, B. (1994). How to (and not to) use bureaucracy with independent distributors. Industrial Marketing Management, 23 (3) 191-197.

6. Bradach, J.L. and Eccles, R.G. (1989). Price, authority, and trust. Annual Review of Sociology, 15, 97-118.

7. Brown, J.R. and Dev, C.S. (1997). The franchisor-franchisee relationship. Cornell Hotel and Restaurant Administration Quarterly, 38 (6) 30-38.

8. Brown, J.R., Dev. C.S., and Lee, D.J. (2000). Managing marketing channel opportunism: the efficacy of alternative governance mechanism. Journal of Marketing, 6 (2) 51-65.

9. $\quad$ Buckling, L.P. (1973). A theory of channel control. Journal of Marketing, 37 (January) 39-47.

10. Cannon, J.P., Achrol, R.S., and Gundlach, G.T. (2000). Contracts, norms and plural form governance. Journal of the Academy of Marketing Science, 28 (2) 180-194.

11. Dahlstrom, R. and Nygaard, A. (1995). An exploratory investigation of interpersonal trust in new and mature market economies. Journal of Retailing, 71 (4) 339-362.

12. Dahlstrom, R. and Nygaard, A. (1999). An empirical investigation of ex-post transaction costs in franchised distribution channels. Journal of Marketing Research, 36 (2) 160-170.

13. Dwyer, R., Schur, P. and Oh, S. (1987). Developing buyer-seller relationships. Journal of Marketing, 51 (2) 11-27.

14. Emerson, R.M. (1962 [1981]). Social exchange theory, in Social Psychology: Sociological Perspectives, eds. M. Rosenberg and R.H. Turner. New York : Basic Books, 30-65.

15. Ferguson, R.J., Paulin, M., and Bergeron J. (2005). Contractual governance, relational governance and the performance of interfirm service exchanges. Journal of the Academy of Marketing Science, 33 (2) 217-234.

16. Gundlach, G.T. and Achrol, R.S. (1993). Governance in exchange: contract law and its alternatives. Journal of Public Policy \& Marketing, 12 (2) 141-155.

17. Gundlach, G.T., Achrol, R.S., and Mentzer, J. (1995). The structure of commitment in exchange. Journal of Marketing, 59 (January) 78-92.

18. Hadfield, G. (1990). Problematic relations: franchising and the law of incomplete contracts. Stanford Law Review, 42 927-992.

19. Heide, J.B. (1994). Interorganizational governance in marketing channels. Journal of Marketing, 58 (1) 7198.

20. Heide, J.B. and John, G. (1992). Do norms matter in marketing relationships? Journal of Marketing, 56 (2) 32-44.

21. Hibbard, J.D., Brunel, F.F., Dant, R.P. and Iacobucci, D. (2001). Does relationship marketing age well? Business Strategy Review, 12 (4) 29-35.

22. Jap, S.D. and Anderson, E. (2001). Safeguarding interorganizational performance and continuity under expost opportunism, Working Paper, INSEAD (April).

23. Jap, S.D. and Ganesan, S. (2000). Control mechanisms and the relationship life cycle: implications for safeguarding specific investments and developing commitment. Journal of Marketing Research, 37 (May) 227-245.

24. Jeuland, A.P. and Shugan, S.M. (1983). Managing channel profits. Marketing Science, 2 (3) $239-272$.

25. Joshi, A.W. and Arnold, S.J. (1997). The impact of buyer dependence on buyer opportunism in buyer supplier relationships: the moderating role of relational norms. Psychology \& Marketing, 14 (8) 823-845.

26. Kumar, N., Scheer, L. K. and Steenkamp, E.M. (1995), The effects of supplier fairness on vulnerable resellers. Journal of Marketing Research, 32 (1) 54-65.

27. Lusch, R.F. and Brown, J.R. (1996), Interdependency, contracting, and relational behavior in marketing channels. Journal of Marketing, 60 (4) 19-38.

28. MacCaulay, S. (1963). Non contractual relations in business: a preliminary study. American Sociological Review, 28 (1) 55-70.

29. McNeil, I.R. (1974). The many futures of contract. Southern California Law Review, 47 (3) $691-816$.

30. McNeil, I.R. (1980). Power, contract, and the economic model. Journal of Economic Issues, 11 (4) $909-$ 923.

31. Noordewier, T.G. , John, G., and Nevin, J.R. (1990), Performance outcomes of purchasing arrangements in industrial buyer-vendor relationships. Journal of Marketing, 54 (October) 80-93. 
32. Samaha, S., Palmatier, R.W., and Dant, R.P. (2011). Poisoning relationships: perceived unfairness in channels of distribution. Journal of Marketing, 75 (May) 99-117.

33. Sindhav, V.B. (2001). The role of organizational justice in managing change within marketing channels. Journal of Marketing Channels, 9 (1/2) 65-91.

34. Spriggs, M.T. (1996). The new social contract: an inquiry into modern contractual relations. Journal of Public Policy \& Marketing, 15 (11) 157-159.

35. Tyler, T. (1988). What is procedural justice? Criteria used by citizens to assess the fairness of legal procedures. Law and Society Review, 22 (1) 301-355.

36. Weitz, B.A. and Jap, S.D. (1995). Relationship marketing and distribution channels. Journal of the Academy of Marketing Science, 23 (4) 305-320.

37. Wuyts, S. and Geyskens, I. (2005). The formation of buyer-supplier relationships: Detailed contract drafting and close partner selection. Journal of Marketing, 69 (4) 103-117.

38. Young, L.C. and Wilkinson I.F. (1989). The role of trust and co-operation in marketing channels: a preliminary study. European Journal of Marketing, 23 (2) 109-122. 


\section{$\underline{\text { NOTES }}$}

